\title{
FIRST- AND THIRD-PERSON PERSPECTIVES ON A MONETARY SAVINGS PROPOSITION MADE IN THE FUTURE TIME MODE
}

\author{
Oleksiy POLUNIN \\ Visiting researcher \\ at the Institute of Experimental Psychology, Slovak Academy of Sciences \\ Dubravska cesta 9, 81364 Bratislava, Slovak Republic \\ Institute of Social and Political Psychology \\ vul. Andrievska 15, Kyiv, 04070 Ukraine \\ E-mail: polunin-alex@yandex.ru
}

\begin{abstract}
The research study reveals a subjective readiness to wait for an advertised monetary savings presented from the first- and third-person perspectives. The properties of simple waiting were studied in relation to the personal perspective on savings proposition and the level of monetary savings. Findings for the first-person perspective replicate our previous results, the propositions in the present time mode with high and low relative savings have high preference and lead to the framing effect, similar to the one described by Tversky and Kahneman (1981). When they are formulated in the future time, both of them loose their attractiveness because of the need of waiting. Unlike savings propositions formulated in the present time mode from the third person perspective, in this case the classical framing effect is eliminated. When the tasks are formulated from the third person perspective with a savings proposition in the future, a pronounced framing effect was found. This result is attributed to the differential impact of waiting time on the propositions with different levels of relative savings. The discrepancy found by this study is the key property of the differentiation between the first- and the third-person perspectives in terms of waiting for a savings proposition made in the future.
\end{abstract}

Key words: decision-making, personal perspective, topical mental account, framing effect, temporal process, waiting

\section{INTRODUCTION}

Conventionally, time is seen as a kind of receptacle in which different processes take place: human interactions, economic exchanges, and expectations. An impact of time processing on human behavior can be

Acknowledgement: This research was supported by the grant from the National Scholarship Programme of the Slovak Republic. examined on two levels: a general and a local one. A time concept integrated in language has a general impact on human behavior. In an extensive study on language use in many countries, Chen (2013) has shown that the ways a language encodes time, especially the future mode, essentially predefines human behavior. He examined the hypothesis that languages that grammatically associate the future and the present, foster future-oriented behavior. According to his results, speakers of such

DOI: $10.21909 /$ sp.2014.04.664 
languages "save more, retire with more wealth, smoke less, practice safer sex, and are less obese".

Under local impact, we mean the influence of temporal information given within a certain situation. A cognitive encoding of a single problem-situation depends on the time markers set within the wording of the problem. Thereafter, the encoding and processing of temporal information shape the behavior. A number of studies show how time processing manifests itself in decisionmaking (Ariely, Zakay, 2001; Klapproth, 2008). In this study, we focus on the local impact of time processing, namely on the subjective acceptability of waiting for monetary savings. Unlike conventional studies on intertemporal decision-making (Frederic, Loewenstein, O'Donoghue, 2002), our study takes into account not only the first but also the third-person perspective, which constitutes the novelty of our results. A monetary savings proposition will be constructed similarly to Tversky and Kahneman's (1981) "Jacket and calculator problem", where a subject develops a separate cognitive representation for each proposition. Thus, a change of the cognitive representation of a proposition will be studied under the impact of waiting.

\section{TEMPORAL PROCESSES IN THE FUTURE TIME MODE}

Future time is of interest as a container of possibilities, as a domain of potential behavioral acts, and a scene for wins and losses. Considering time as a complex domain, we have shown that it includes a scope for temporal processes (Polunin, 2009, 2011). The discrepancies between the temporal processes rest upon the psycho- logical differences in the representation of time flow, action and action outcome. In the current study, only the properties of the zero-probability-barrier will be studied. A zero-probability-barrier, as a temporal process, represents a kind of potentially available future, but not reachable from the present moment. It is "pure", forced waiting. Such waiting is forced, in the sense that it is not in the subject's power to use a sale proposition until a certain date; for instance, to go earlier to an advertised summer sell-out in order to get a better price for a particular desired commodity. There is a number of such sell-outs in real life, e.g. Christmas sale, waiting for the announcement of the beginning of the sale on a new Apple-product, waiting for the day when you get your dividends paid or cash in your coupons. In all these cases, the future possibility of monetary savings is separated from the present time by a time-interval, within which the probability to use the savings proposition is equal to zero. This is why such waiting is called a "zero-probability-barrier". The subjective representation of zero-probability-barrier can be moderated by a number of variables. The current study aims to specify the properties of such waiting 1) in relation of the first- and the third-person perspective (1PP vs. 3PP), and 2) in regards to the absolute and relative amounts of savings. In order to study the impact of these variables on the decision outcome, a percentage of positive responses and a manifestation of the framing effect will be analyzed. Therefore, the main question raised here is as follows: How does the change of personal perspective influence the effect of the zero-probabilitybarrier on the decision about a monetary savings proposition? 


\author{
The First-Person and \\ the Third-Person-Perspective \\ on Monetary Savings
}

Social interactions rely on our ability to distinguish between a personal perspective and a perspective on the part of others (Decety, Sommerville, 2003). In social transactions, we exchange resources, feelings, plans and prepare group actions. Such transactions involve both an ability to identify with others, and also an ability to distinguish ourselves from others. The first person perspective (1PP) helps us to express our own goals, expectations and readiness to act. But the third person perspective (3PP) enables us to take the view-point of someone else, and based on that, to correct our own plans and expectations. Integrating these two perspectives constitutes the success of social interactions and provides the fruitfulness of exchange of values. Thus, in this study we use two different wordings of a problem: first half of the tasks is given from the 1PP, and the second half is formulated from the 3PP. The first-person-perspective helps to model the subject's own decision. And the thirdperson perspective reflects the expectations of the action of another person in a similar situation. For mapping a cognitive representation of a savings proposition to a third person, our subject (the first person) will be asked to make a decision on the part of a third person ${ }^{1}$. The introduced variation of the personal perspective changes the person who is saving money, consequently, it must modulate the decision outcome and manifestation

\footnotetext{
${ }^{1}$ In this study another student will be the third person, so that the $1^{\text {st }}$ and the $3^{\text {rd }}$ person have a comparably equal monthly income.
}

of the corresponding framing effect in the sense of Tversky and Kahneman (1981).

Making a decision from the 1PP, a subject decides whether the proposed savings is attractive enough for him/herself. In case of making a decision from the $3 \mathrm{PP}$, a subject has to assess whether the other subject will accept a savings proposition. The studies on human overconfidence provide strong evidence for overestimating one's own abilities, knowledge and accuracy of one's own actions. People tend to give favorable assessments of their own abilities (Alicke, 1985; Dunning et al., 1989). Thus, another student taken as a third person in the decision-making task should, on average, be underestimated compared to the subject acting from the first person perspective. On average, the other student must be seen as having a lower monthly income and, therefore, being more inclined to go for monetary savings. Correspondingly, hypothesis 1 is: a general number of positive responses to a monetary savings proposition will be higher for tasks formulated from the third-person perspective than those from the first-person-perspective.

Taken together, an underestimation of the monthly income of the third person with an overestimation of the personal disposition of an average student (3PP) towards a saving behavior, we should expect the elimination of the difference between the relative levels of monetary savings, at least for propositions in the present time mode. Considering the fact that the relative amount of monetary savings is the key factor in the manifestation of the framing effect in topical mental accounting (Tversky, Kahneman, 1981; Moon et al., 1999), the following assumption for the decisions in the name of the third person can be made: the declined role of the relative amount of monetary sav- 
ings and the increased role of the absolute amount of savings lead to similarity in positive responses to absolutely equal but relatively different savings propositions and, consequently, this results in a declining framing effect up to its total elimination (hypothesis 2). For decisions made from the 1PP, the classical framing effect (Tversky, Kahneman, 1981) is to be expected.

\section{Impact of Zero-Probability Barrier on Topical Mental Account}

The first-person perspective on the zeroprobability barrier. Due to the topicality of the mental account, the same amount of money proposed to be saved can lead to different decision outcomes, known as the framing effect (Tversky, Kahneman, 1981; Kühberger, 1998; Levin et al., 1998; Ranyard, Abdel-Nabi, 1993). But most of the studies on topical mental account and the corresponding framing effect use tasks with propositions formulated in the present time. However, in real life not all propositions are about the wins or losses at the present time (Frederick et al., 2002). For savings propositions beginning in the future, a zero-probability-barrier seems to be one of the key factors predefining the level of its subjective attractiveness. Thus, the corresponding change in subjective attractiveness of a proposition and a change in the manifestation of the framing effect is to be expected.

When a savings proposition is separated from the present moment by a zero-probability-barrier, a number of positive responses to the proposition declines. But such decline runs quite equally for both the low and high relative savings, so that the framing effect "survives" when a subject is forced to wait for a while (Polunin, 2009, 2011). Thus, in this study we also expect a general decline, almost in parallel, in positive responses for both, savings propositions with low and high relative savings. The absolute level of monetary savings should impact the general attractiveness of a savings proposition, so that the higher absolute savings become more positive responses, while the size of the framing effect remains more or less the same.

The third-person perspective on the zeroprobability barrier. According to Freyd (1987, 1992), each cognitive representation has its own temporal dimension. Therefore, the mental representation of a third person and the proposition made to him/her should also have its own temporal dimension, which is a different one from the temporal dimension activated for a first person perspective. This distinctiveness also means a different impact of zero-probability-barrier, applied once to a subject him/herself (1PP) and once to the third person (3PP). Thus, we assume that the properties of a zero-probability-barrier depend on the personal perspective from which this temporal process unfolds. This should result in different decision outcomes in relation to the same savings proposition.

The question a subject answers for him/ herself in the 1PP decision is the following: Should I wait a while and get a better price for an item (headphones)? The answer is determined by his/her subjective impatience and subjective evaluation of the proposed savings. But for the 3PP, a positive decision can be based on the subjective assessment of impatience of another person (3PP) and his/her personal disposition to save money. The question to answer is whether another student will be inclined to wait few days for the monetary savings? The discrepancy between the decision-outcomes for the 1PPand 3PP-task should rest upon the differen- 
tial inhibitive impact of zero-probability-barrier.

Do the subjects predict that others will be similarly ready to wait and save? Considering that people themselves are largely waiting-averse in their gaining decisions, but generous with time as a resource of others and only partly able to empathize with the waiting aversion of others, we assume (hypothesis 3 ) that people would be less waiting-oriented when the decision context is selffocused than when it is other-focused. According to this assumption, for the tasks formulated from the 1PP we should expect a generally stronger inhibiting effect of the zero-probability-barrier than for the tasks formulated from the 3PP. At the same time, a differential impact of zero-probability-barrier on low and high relative savings proposed to the third person is not to be excluded, because it was found for an aging of savings proposition in case of a $3 \mathrm{PP}$ in the past time mode (Polunin, 2013).

In order to examine the hypotheses discussed above, we first reproduced a classical framing effect, similar to one described by Tversky and Kahneman (1981), which was taken as a basis for analysis of impact of all other factors.

\section{METHOD}

\section{Design}

The method is similar to the one used in previous studies (Polunin, 2009, 2011, 2013). The experimental task is adapted from the "Jacket and calculator" problem (Tversky, Kahneman, 1981), which provides a sustainable framing effect. The modified decision problems include the following independent variables: time variable (present-future), the parameters of savings proposition (a relative and an absolute level of monetary savings) and personal perspective (1PP vs. 3PP). The prices in the decision problem were adjusted to the actual range of prices at the local electronics store. All together there were sixteen versions of the same basic scenario: time mode (present, future) $\mathrm{x}$ two versions of task wording $(33.3 \%$ and $5 \%$ of relative price reduction) $\mathrm{x}$ two levels of absolute price reduction (30 $\mathrm{UAH}$ and $50 \mathrm{UAH}^{2}$ ) $\mathrm{x}$ two versions of person-perspective (1PP vs. 3PP), see Table 1. A subject's decision outcome was taken as the dependent variable showing his/her readiness to accept a savings proposition. The between subjects experimental design was applied, which is usual for these studies (Kühberger, 1998).

\section{Materials}

Written versions of the problem were prepared in Ukrainian. A similar wording was used in each case and only the amount of money to be saved and the temporal parameters of the situation were changed. Considering the fact, that the activations of a personal perspective can be induced just by task wording, namely the use of corresponding personal pronouns, we prepared two types of task wordings (1PP vs. 3PP). The tasks for the $1 \mathrm{PP}$ were formulated similarly to the wordings used in a previous study (Polunin, 2009, 2011). For the "third-person perspective" condition, the task wording bellow was used. The participants were asked to predict what another student would decide.

\footnotetext{
${ }^{2}$ At the time of data collection the exchange rate in Kyiv was about 8.02-8.05 UAH (Ukrainian hryvnia) for 1 USD, and about 10.43-10.62 UAH for 1 EUR.
} 
Table 1. The design of the experiment. The original prices were $1000 \mathrm{UAH}$ and $150 \mathrm{UAH}$ for the price reduction of $50 \mathrm{UAH}$, and $600 \mathrm{UAH}$ and $90 \mathrm{UAH}$ for the price reduction of $30 \mathrm{UAH}$

\begin{tabular}{|c|c|c|c|c|}
\hline \multirow{2}{*}{$\begin{array}{l}\text { Time mode and } \\
\text { absolute } \\
\text { savings }\end{array}$} & \multicolumn{2}{|c|}{$1^{\text {st }}$ person perspective } & \multicolumn{2}{|c|}{$3^{\text {rd }}$ person perspective } \\
\hline & savings $5 \%$ & savings $33.3 \%$ & savings $5 \%$ & savings $33.3 \%$ \\
\hline $\begin{array}{l}\text { Present, } 0 \text { days, } \\
\text { 50UAH }\end{array}$ & $\begin{array}{c}1000-50=950 \\
\text { UAH }\end{array}$ & $\begin{array}{c}150-50=100 \\
\text { UAH }\end{array}$ & $\begin{array}{c}1000-50=950 \\
\text { UAH }\end{array}$ & $\begin{array}{c}150-50=100 \\
\text { UAH }\end{array}$ \\
\hline $\begin{array}{l}\text { Future } 3 \text { days } \\
\text { 50UAH }\end{array}$ & $\begin{array}{c}1000-50=950 \\
\text { UAH }\end{array}$ & $\begin{array}{c}150-50=100 \\
\text { UAH }\end{array}$ & $\begin{array}{c}1000-50=950 \\
\text { UAH }\end{array}$ & $\begin{array}{c}150-50=100 \\
\text { UAH }\end{array}$ \\
\hline $\begin{array}{l}\text { Present, } 0 \text { days } \\
\text { 30UAH }\end{array}$ & $\begin{array}{c}600-30=570 \\
\text { UAH }\end{array}$ & $\begin{array}{c}90-30=60 \\
\text { UAH }\end{array}$ & $\begin{array}{c}600-30=570 \\
\text { UAH }\end{array}$ & $\begin{array}{c}90-30=60 \\
\text { UAH }\end{array}$ \\
\hline $\begin{array}{l}\text { Future } 3 \text { days } \\
\text { 30UAH }\end{array}$ & $\begin{array}{c}600-30=570 \\
\text { UAH }\end{array}$ & $\begin{array}{c}90-30=60 \\
\text { UAH }\end{array}$ & $\begin{array}{c}600-30=570 \\
\text { UAH }\end{array}$ & $\begin{array}{c}90-30=60 \\
\text { UAH }\end{array}$ \\
\hline
\end{tabular}

Task 1, 3PP for proposition made in the present time mode.

Please, imagine the following situation, and make a decision about it.

Imagine that a fellow student comes to an electronics store and is about to purchase:

headphones for $150 \mathrm{UAH}$

and a microphone for $1000 \mathrm{UAH}$.

The student chooses the headphones, but a shop assistant informs him/her that the same headphone is on sale for $100 \mathrm{UAH}$ at the other branch of the store, located 20 minutes drive away.

Would the student make the trip to the other store? (check one box)

$$
\text { YES } \bar{\square} \quad \text { NO } \bar{\square}
$$

For the "third-person perspective in the future time mode" condition the task was formulated as follows.

Task 1, 3PP for proposition made in the future time mode.

Please, imagine the following situation, and make a decision about it.
Imagine that a fellow student comes to an electronics store and is about to purchase: headphones for $150 \mathrm{UAH}$ and a microphone for $1000 \mathrm{UAH}$.

The student chooses the headphones, but a shop assistant informs him/her that the same headphones will be on sale in 3 days for $100 \mathrm{UAH}$ at the other branch of the store, located 20 minutes drive away.

Would a student make the trip to the other store? (check one box)

$$
\text { YES } \bar{\square} \quad \text { NO } \bar{\square}
$$

Task 2 was formulated similarly, only the absolute and relative amounts of savings were changed according to the design of the experiment.

\section{Subjects}

1104 students ( 69 subjects for each of the16 experimental conditions) between the ages of 17 and 29 (mean age 19.1 years; $78 \%$ males and $22 \%$ females) participated in the experi- 
ment. The participation was voluntary and unpaid. Each subject solved only one decision problem and none of the subjects participated in the experiment repeatedly. The number per session ranged from 12 to 36 subjects.

\section{RESULTS}

The percentage of positive responses to a savings proposition within each experimental condition is presented in Table 2. But be-

Table 2. The percentage of positive responses for each experimental condition

\begin{tabular}{|c|c|c|c|c|c|c|}
\hline \multirow[b]{2}{*}{$\begin{array}{l}\text { Time mode and } \\
\text { absolute savings }\end{array}$} & \multicolumn{3}{|c|}{$1^{\text {st }}$ person perspective } & \multicolumn{3}{|c|}{$3^{\text {rd }}$ person perspective } \\
\hline & $\begin{array}{c}\text { savings } \\
5 \%\end{array}$ & $\begin{array}{l}\text { savings } \\
33.3 \%\end{array}$ & $\begin{array}{l}\text { size of framing- } \\
\text { effect, } \% \text {, signif. }\end{array}$ & $\begin{array}{c}\text { savings } \\
5 \%\end{array}$ & $\begin{array}{l}\text { savings } \\
33.3 \%\end{array}$ & $\begin{array}{l}\text { size of framing- } \\
\text { effect, } \% \text {, signif. }\end{array}$ \\
\hline $\begin{array}{l}\text { Present, } 0 \text { days } \\
50 \text { UAH }\end{array}$ & $50.7 \%$ & $66.7 \%$ & $\begin{array}{l}16 \% \\
\chi^{2}=3.6, \mathrm{df}=1 \\
\mathrm{p}=.058 \\
\text { marginal sign. }\end{array}$ & $69.6 \%$ & $73.9 \%$ & $\begin{array}{l}4.3 \% \\
\chi^{2}<1 \\
\text { non sign. }\end{array}$ \\
\hline $\begin{array}{l}\text { Difference in \% } \\
\text { of "yes" } \\
\text { between Present } \\
\text { and Future } \\
\text { conditions }\end{array}$ & $\begin{array}{l}\Delta=10.1 \% \\
\chi^{2}=1.4 \\
\mathrm{df}=1 \\
\mathrm{p}=.23 \\
\text { non sign. }\end{array}$ & $\begin{array}{l}\Delta=8.7 \% \\
\chi^{2}=1.1 \\
\mathrm{df}=1 \\
\mathrm{p}=.29 \\
\text { non sign. }\end{array}$ & - & $\begin{array}{l}\Delta=29 \% \\
\chi^{2}=11.7 \\
d f=1 \\
p=.001\end{array}$ & $\begin{array}{l}\Delta=2.9 \% \\
\chi^{2}<1 \\
\mathrm{df}=1 \\
\text { non sign. }\end{array}$ & - \\
\hline $\begin{array}{l}\text { Future, } 3 \text { days } \\
50 \text { UAH }\end{array}$ & $40.6 \%$ & $58 \%$ & $\begin{array}{l}17.4 \% \\
\chi^{2}=4.2, \mathrm{df}=1 \\
p=.04\end{array}$ & $40.6 \%$ & $71 \%$ & $\begin{array}{l}30.4 \% \\
\chi^{2}=14, \mathrm{df}=1 \\
p<.001\end{array}$ \\
\hline $\begin{array}{l}\text { Present, } 0 \text { days, } \\
30 \text { UAH }\end{array}$ & $42 \%$ & $59.4 \%$ & $\begin{array}{l}17.4 \% \\
\chi^{2}=4.2 \\
p=.04\end{array}$ & $62.3 \%$ & $69.6 \%$ & $\begin{array}{l}7.3 \% \\
\chi^{2}<1 \\
\text { non sign. }\end{array}$ \\
\hline $\begin{array}{l}\text { Difference in \% } \\
\text { of "yes" } \\
\text { between Present } \\
\text { and Future } \\
\text { conditions }\end{array}$ & $\begin{array}{l}\Delta=4.3 \% \\
\chi^{2}<1 \\
d f=1 \\
\text { non sign. }\end{array}$ & $\begin{array}{l}\Delta=10.1 \% \\
\chi^{2}=1.4 \\
d f=1 \\
p=0.23 \\
\text { non sign. }\end{array}$ & - & $\begin{array}{l}\Delta=21.7 \% \\
\chi^{2}=\mathbf{6 . 5} \\
\mathrm{df}=1 \\
\mathrm{p}=.011\end{array}$ & $\begin{array}{l}\Delta=4.4 \% \\
\chi^{2}<1, \\
\text { df }=1 \\
\text { non sign. }\end{array}$ & - \\
\hline $\begin{array}{l}\text { Future, } 3 \text { days } \\
\text { 30 UAH }\end{array}$ & $37.7 \%$ & $49.3 \%$ & $\begin{array}{l}11.6 \% \\
\chi^{2}=1.9, \mathrm{df}=1 \\
p=.17 \\
\text { non sign. }\end{array}$ & $40.6 \%$ & $65.2 \%$ & $\begin{array}{l}24.6 \% \\
\chi^{2}=8.4, d f=1 \\
p=.004\end{array}$ \\
\hline
\end{tabular}

Note: Size of the framing effect was calculated as the difference between the corresponding conditions with $33.3 \%$ and $5 \%$ savings. An effect of zero-probability-barrier is given as the difference in $\%$ of "yes" between the Present and Future conditions. This difference presents the inhibitive impact of zero-probability-barrier on the readiness to accept the savings proposition. 
fore examining our hypotheses on the framing effect, the main effects of certain single factors were analyzed to demonstrate the general tendencies in decision-making under given experimental conditions. We found a significant main effect of the time mode, present time vs. future. In all conditions, the number of "yes" responses for the present time mode was $55.1 \%$ and for the future time condition it was $44.9 \%, \chi^{2}=14.6, \mathrm{df}=1, \mathrm{p}<$ 0.001 . This finding only replicates the wellknown truth that humans prefer not to wait, even when the probability to reach a goal does not decline. Thus, the zero-probability-barrier has an inhibitive impact on readiness to act under all experimental conditions.

As we have assumed, we found a main effect of the personal perspective. A general number of positive responses given to a monetary savings proposition is higher for tasks formulated from the 3PP (54.9\%) than from the 1PP $(45.1 \%), \chi^{2}=13.6, \mathrm{df}=1, \mathrm{p}<$ .001 . This effect is especially pronounced for the present time mode condition (Table 2). Thus, over all conditions, hypothesis 1 is true. This finding replicates the results of our previous study (Polunin, 2013), where positive decisions on savings propositions made in the first-person were significantly lower than in the third-person. We can argue that the cognitive representation of the third person systematically differs from that of the first-person, having an impact on the decision outcomes.

We also analyzed an impact of the amount of monetary savings on decision outcome. The main effect of the absolute level of monetary savings, (30 UAH vs. $50 \mathrm{UAH}$ ) in all conditions was marginally significant $\left(\chi^{2}=\right.$ $3.5, \mathrm{df}=1, \mathrm{p}=.06)$. So, an increase of absolute savings proposition from $30 \mathrm{UAH}$ to 50 UAH leads to an almost significant increase in the percentage of positive responses, correspondingly from $47.5 \%$ of "yes" up to $52.5 \%$ of "yes". Obviously, both 30 UAH and $50 \mathrm{UAH}$ savings have a quite high subjective value for our subjects and the difference between these two absolute savings is not enough to cause a pronounced effect. Considering the results of a previous study (Polunin, 2013), where the $40 \mathrm{UAH}$ and $60 \mathrm{UAH}$ savings were applied, we may argue that the upper threshold for absolute savings begins at 50-60 UAH, at least for the students of Technical University Kiev. The higher absolute savings amount, given also as high relative savings, will be accepted by the majority of students.

The relative level of monetary savings ( $5 \%$ vs. $33.3 \%$ saving) shows its significant impact $\left(\chi^{2}=29, \mathrm{df}=1, \mathrm{p}<.001\right)$ on decisions made. In our data, $57.2 \%$ of "yes" responses were given to $33.3 \%$ savings, while just $42.8 \%$ of "yes" responses were given to a 5\%-saving. The main gender effect was not significant, $\chi^{2}=1.4, \mathrm{df}=1, \mathrm{p}=0.24$. Such finding is in line with our earlier results.

First-vs. third-person perspective in the present time mode. Two versions of proposition wording $(33.3 \%$ and $5 \%$ ), given from the 1PP in the present time mode, leads to the framing effect (for $30 \mathrm{UAH} \chi^{2}=4.2, \mathrm{df}=1$, $\mathrm{p}=.04$ and for $50 \mathrm{UAH} \chi^{2}=3.6, \mathrm{df}=1, \mathrm{p}=$ .058 ), which is the classical finding described by Tversky and Kahneman (1981). On the other hand, in case of the proposition formulated from the 3PP in the present time mode, no significant framing effect was found. In both cases, for $30 \mathrm{UAH}$ and 50 UAH savings, no significant difference was found between the responses given to $5 \%$ and $33.3 \%$ of relative savings, $\chi^{2}<1$, see Table 2. The elimination of the framing effect for the tasks formulated in the present time 
mode from the 3PP shows that hypothesis 2 is true. In the present time mode, the declined role of the relative amount of monetary savings and the increased importance of the absolute amount of savings leads to almost similar number of positive responses for both high and low relative savings. Consequently, this results in statistically non-significant difference between these two savings propositions. Therefore, a subject making a decision in the name of a third person considers the absolute amount of savings.

\section{Effect of Zero-Probability-Barrier on Acceptance of Savings Proposition}

For propositions made from the 1PP, the zero-probability-barrier has a quite similar impact on low and high absolute savings. The readiness to accept a proposition declines parallelly in the transition from the present to the future time moment (Figure 1a, 1b), which is in an agreement with our earlier study (Polunin, 2009). The framing effect remains for the savings propositions made from the 1PP, so that the zero-probability-barrier causes a decrease of the general attractiveness of the savings proposition. For the tasks formulated from the 3PP, the effect of zero-probability-barrier looks very different. Here the absence of a significant framing effect in the present time mode changes into a pronounced framing effect in the future time mode (Figure 1c, 1d).

The difference in the effect of the zeroprobability-barrier between the 1PP and the 3PP depends on the relative amount of savings. The impact of the zero-probability-barrier for the 1PP task formulation is almost independent of the level of relative savings (Figure 1a, 1b). But for the tasks formulated from the 3PP, the zero-probability-barrier dra- matically affects the attractiveness of the low relative savings proposition, causing its deep decline (Table 2). On the other hand, the high relative savings proposition shows a small decline of attractiveness. So, an interaction of the zero-probability-barrier with the relative level of savings was found $(\mathrm{F}=$ $7.3, \mathrm{df}=1, \mathrm{p}=.007)$. For the $3 \mathrm{PP}$, the readiness to wait significantly interacts with the level of relative savings, and, as result, a difference in decision outcomes for the low and high relative savings arises (Figure 1c, 1d). This discrepancy causes the significant framing effect for the 3PP tasks in future time mode. The described difference between the $1 \mathrm{PP}$ and 3PP should be considered as a potential source of disagreements between the self and others on future monetary transactions and values exchange.

Based on these findings, one can specify the difference between the zero-probabilitybarrier and an aging of proposition in the past time mode (Polunin, 2013). An aging process under comparable conditions causes a significant loss of proposition attractiveness for the 1PP as well as 3PP, and for both the low and high relative savings as well.

According to hypothesis 3, a stronger inhibiting effect of the zero-probability-barrier must be observed for the tasks formulated from the 1PP than for the tasks formulated from the 3PP. The refusal to wait is manifested by the loss of the positive responses between the present and future time mode (Table 2). The results show that hypothesis 3 is only partly true, namely for the high relative savings. Obviously, the waiting time has a different impact on the loss of positive responses depending on the personal perspective, and relative level of savings proposition. The interaction "time mode" $\mathrm{x}$ "personal perspective" $x$ "relative savings" reaches the 
1PP, 50 UAH

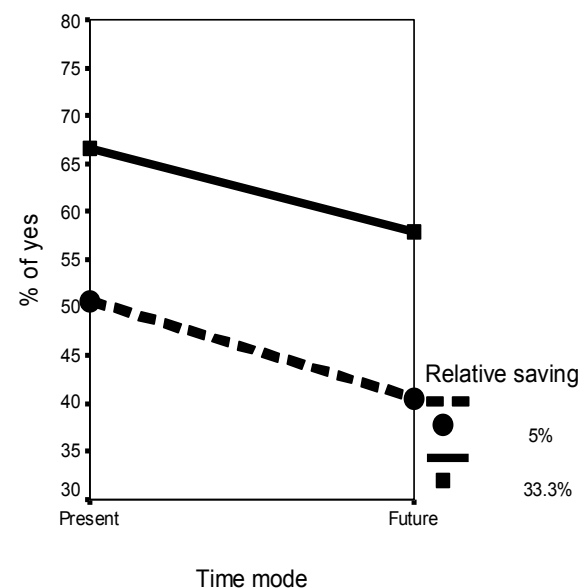

Fig. 1a.

3PP, 50 UAH

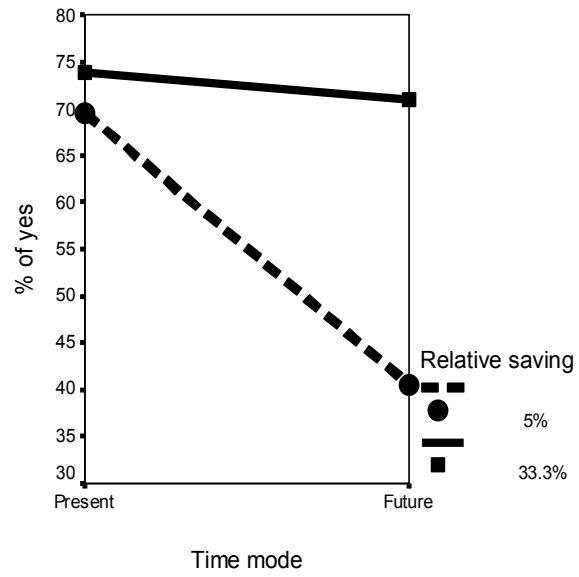

Fig. 1c.
1PP, $30 \mathrm{UAH}$

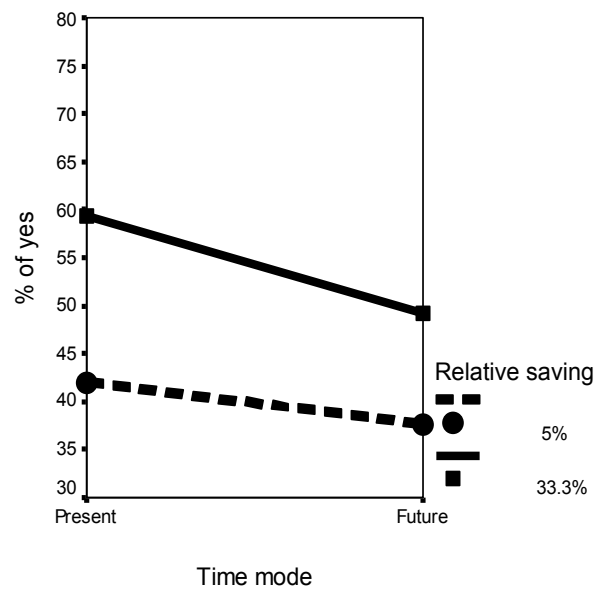

Fig. 1b.

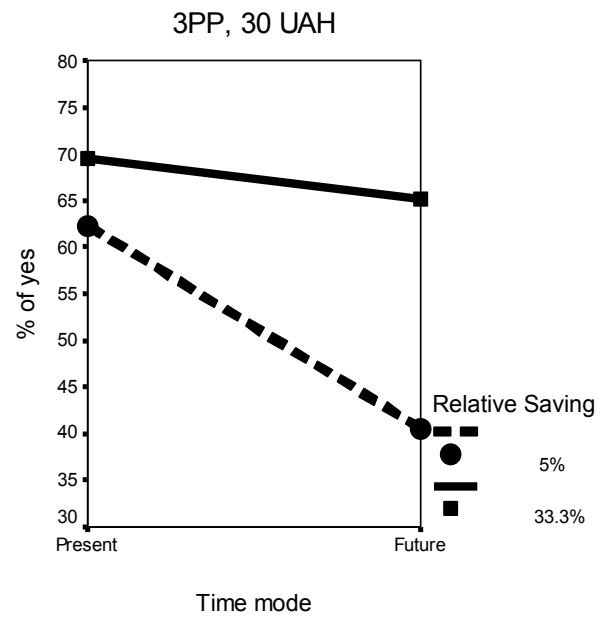

Fig. 1d.

Figure 1a, b, c, d. Changes in number of "yes" responses by transition from the present to the future time mode. Figures $1 \mathrm{a}$ and $1 \mathrm{~b}$ present the results for 1PP-tasks, whereas Figures $1 \mathrm{c}$ and $1 \mathrm{~d}$ present the 3PP-tasks. The difference in positive responses between the $33.3 \%$ and $5 \%$ savings presents the framing effect. An inhibition to accept a savings proposition caused by zero-probability-barrier is presented by the difference between the present and future conditions. An angle between each line and horizon reflects the corresponding strength of inhibition. 
level of significance, $\mathrm{F}=4.22, \mathrm{df}=1, \mathrm{p}=0.04$. For the $33.3 \%$ relative savings for both absolute savings the averaged loss of proposition attractiveness for $1 \mathrm{PP}$ is $9.4 \%$, whereas for the $3 \mathrm{PP}$ it equals $3.65 \%$. On the other hand, the loss of positive responses is the highest for the task formulated from the 3PP with 5\% savings, on average, for both levels of absolute savings it equals $25.35 \%$; when the savings was 5\% the loss of "yes" for the $1 \mathrm{PP}$ was only $7.2 \%$, averaged for both levels of absolute savings.

\section{DISCUSSION}

Taking into account the idea about time as a universal value, we argue that the processing of temporal information, once attributed to the self and once to the other person, plays a key role in organization of our behavior, including decision-making concerning monetary savings. The results replicate the framing effect for the tasks formulated from the first-person perspective, when a proposition is made in the present time mode. But the current as well as a previous study (Polunin, 2013) have shown that the classical framing effect is eliminated, when the savings proposition is made in the present time mode but in the third-person perspective. The study also demonstrates that the dynamics of the framing effect in the future time mode for the tasks formulated from the first- and the thirdperson perspectives differ substantially. When the savings proposition is realized in future time, the framing effect for the 1PP remains pronounced and just the general number of positive responses given to both tasks declines. On the other hand, in case of the 3PP tasks, the framing effect, absent in the present time mode, appears when the savings proposition is realized in the future.
These results point to a discrepancy in topical mental accounts running over time from the perspective of the first- and the thirdperson, and widen the list of the already known experimental designs relevant in the manipulation of the framing effect, as overviewed by Kahneman, Tversky (1984), Kühberger (1998), Levin et al. (1998). The discrepancy that we found between the firstand the third person perspectives and its dependence on the level of relative savings could be of interest for commodities advertisement as well.

This study specifies the inhibition-strength of the zero-probability-barrier, depending on the person-perspective and the absolute and relative levels of monetary savings. Such specification will be helpful for further distinguishing of single temporal processes. For example, the properties of aging in past time mode (Polunin, 2013) and that of zero-probability-barrier in the future time mode seem to be quite similar, but only when a decision problem is formulated from the 3PP. When the decision task is formulated from the 1PP, they differ substantially. This is finally manifested in the size of the framing effect. In this sense, the current study is a step forward in the development of the idea of multiplicity of temporal processes (Polunin, 2009, 2011). One may point to the limitation of the study, which is that students were not explicitly asked about the readiness to save money on their part and on the part of the average student. On the other hand, because of the low level of income in Ukraine, the students' readiness to save money is almost a typical behavior, hardly to be doubted.

The difference found between the 1PP and the 3PP could also be of interest for the studies of the game theory. The results show how the value of money changes depending on 
the personal perspective and waiting time. This discrepancy in a subjective evaluation can be illuminated by two simple sentences marking the very beginning of a partner's disagreement: "I offered you a lot!" vs. "You offered me too little!" Such unfolding of time discrepancy between the first- and the thirdperson perspectives should be considered in game modelling, and in the assessment of a partner's future behavior, in a marital partnership or in other kinds of coalitions. The current results point to the existence of two perspectives on the modelling of a partner's action: 1$)$ he/she behaves as me (3PP $=1 \mathrm{PP})$ or 2) he/she behaves as a third person (3PP $\neq 1 \mathrm{PP})$. Consequently, the very first steps in the game have a kind of double nature. Obviously, such duality will impact the way the whole game develops, from the first steps to the end of the game.

Received June 1, 2013

\section{REFERENCES}

ALICKE, M.D., 1985, Global self-evaluation as determined by the desirability and controllability of trait adjectives. Journal of Personality and Social Psychology, 49, 1621-1630.

ARIELY, D., ZAKAY, D., 2001, A timely account of the role of duration in decision making. Acta Psychologica, 108, 187-207.

CHEN, M.K., 2013, The effect of language on economic behavior: Evidence from savings rates, health behaviors, and retirement assets. American Economic Review, 103, 2, 690-731. Permanent address: http://dx.doi.org/10.1257/aer.103.2.690

DECETY, J., SOMMERVILLE, J.A., 2003, Shared representations between self and other: A social cognitive neuroscience view. Trends in Cognitive Sciences, 1, 12, 527-533.

DUNNING, D., MEYEROWITZ, J.A., HOLZBERG, A., 1989, Ambiguity and self-evalua- tion: The role of idiosyncratic trait definitions in self-serving assessments of ability. Journal of Personality and Social Psychology, 57, 1082-1090.

FREDERICK, S., LOEWENSTEIN, G., O'DONGHUE, T., 2002, Time discounting and time preference: A critical review. Journal of Economic Literature, XL, 351-401

FREYD, J.J., 1987, Dynamic mental representations. Psychological Review, 94, 4, 427-438.

FREYD, J.J., 1992, Dynamic representations guiding adaptive behaviour. In: F. Macar, V. Pouthas, J. Friedman (Eds.), Time, action and cognition (pp. 309-323). Dordrecht: Kluwer.

KAHNEMAN, D., TVERSKY, A., 1984, Choices, values and frames. American Psychologist, 39, 341350 .

KLAPPROTH, F., 2008, Time and decision making in humans. Cognitive, Affective, \& Behavioral Neuroscience, 8, 4, 509-524.

KÜHBERGER, A., 1998, The influence of framing on risky decisions: A meta-analysis. Organizational Behaviour and Human Decision Processes, 75, 1, 23-55.

LEVIN, I.P., SCHNEIDER, S.L., GAETH, G.J., 1998, All frames are not created equal: A topology and critical analysis of framing effects. Organizational Behaviour and Human Decision Processes, 76, 2, 149-188.

MOON, Ph., KEASEY, K., DUXBURY, D., 1999, Mental accounting and decision making: The relationship between relative and absolute savings. Journal of Economic Behavior \& Organization, 38, 145-153.

POLUNIN, O., 2009, Temporal dimension of the framing effect in topical mental accounting. Studia Psychologica, 51, 4, 434-355.

POLUNIN, O., 2011, Temporal processes in the topical mental accounting. Studia Psychologica, 53, 3, 275-291.

POLUNIN, O., 2013, Aging of monetary saving proposition formulated from the first- and the thirdperson perspectives as a factor modulating the framing effect. Studia Psychologica, 55, 2, 123-138.

RANYARD, R., ABDEL-NABI, D., 1993, Mental accounting and the process of multiattributive choice. Acta Psychologica, 84, 161-177.

TVERSKY, D., KAHNEMAN, A., 1981, The framing of decisions and the psychology of choice. Science, 211, 453-458. 


\title{
NÁVRH FINANČNEJ ÚSPORY V BUDÚCNOSTI Z POHLADU PRVEJ A TRETEJ OSOBY
}

\author{
O. Polun in
}

Súhrn: Štúdia odhal'uje subjektívnu pripravenost' čakat' na vopred oznámenú úsporu financií z pohl'adu prvej a tretej osoby. Vlastnosti jednoduchého čakania sme študovali vo vzt'ahu k osobnému pohladu na ná-vrh úspory a mieru finančnej úspory. Zistenia z pohladu prvej osoby replikujú naše predchádzajúce výsledky, návrhy s nízkou a vysokou relatívnou úsporou v súčasnosti sú vysoko preferované a vedú $\mathrm{k}$ efektu rámcovania, podobnému aký opísali Tversky a Kahneman (1981). Ak ich však formulujeme v budúcom čase, oba strácajú prít’ǎlivost' vzhl’adom na potrebu čakat'. $\mathrm{Na}$ rozdiel od návrhu úspory formulovaného $\mathrm{v}$ súčasnosti z pohl’adu tretej osoby, $\mathrm{v}$ tomto prípade sa eliminuje klasický efekt rámcovania. Ak úlohy formulujeme z pohl'adu tretej osoby s návrhom finančnej úspory v budúcnosti, objaví sa výrazný efekt rámcovania. Tento výsledok pripisujeme rozdielnemu vplyvu doby čakania na návrhy s rôznou mierou relatívnej úspory. Rozdiel, ktorý odhaluje táto štúdia je klúčovou vlastnostou rozdielu medzi pohl'adom prvej a tretej osoby na úsporu v budúcnosti. 